\title{
A caspase-8-independent component in TRAIL/Apo- 2L-induced cell death in human rhabdomyosarcoma cells
}

\author{
I Petak ${ }^{1,2}$, R Vernes ${ }^{1,2}$, KS Szucs ${ }^{1}$, M Anozie $^{1}$, K Izeradjene $^{1}$, \\ L Douglas ${ }^{1}$, DM Tillman ${ }^{1}$, DC Phillips ${ }^{1}$ and JA Houghton*,1 \\ ${ }^{1}$ Division of Molecular Therapeutics, Department of Hematology-Oncology, St. \\ Jude Children's Research Hospital, Memphis, Tennesse, USA \\ 2 These authors contributed equally to this work and share first authorship \\ * Corresponding author: JA Houghton, Division of Molecular Therapeutics, \\ Department of Hematology-Oncology, St. Jude Children's Research Hospital, \\ 332 North Launderdale, Memphis, Tennesse, 38105, USA. Tel: 901 495- \\ 3456; Fax: 901 495-3966 E-mail: janet.houghton@ stjude.org
}

Received 26.8.02; revised 30.10.02; accepted 14.1.03

Edited by T Ferguson

\section{Abstract}

Tumor necrosis factor related apoptosis inducing ligand (TRAIL) belongs to the Tumor necrosis factor (TNF) family of death-inducing ligands, and signaling downstream of TRAIL ligation to its receptor(s) remains to be fully elucidated. Components of the death-inducing signaling complex (DISC) and TRAIL signaling downstream of receptor activation were examined in TRAIL - sensitive and -resistant models of human rhabdomyosarcoma (RMS). TRAIL ligation induced DISC formation in TRAIL-sensitive (RD, Rh18, Rh30) and TRAILresistant RMS (Rh28, Rh36, Rh41), with recruitment of FADD and procaspase-8. In RD cells, overexpression of dominantnegative FADD (DNFADD) completely abolished TRAILinduced cell death in contrast to dominant-negative caspase8 (DNC8), which only partially inhibited TRAIL-induced apoptosis, growth inhibition, or loss in clonogenic survival. DNC8 did not inhibit the cleavage of Bid or the activation of Bax. Overexpression of Bcl-2 or Bcl-xL inhibited TRAILinduced apoptosis, growth inhibition, and loss in clonogenic survival. Bcl-2 and Bcl-xL, but not DNC8, inhibited TRAILinduced Bax activation. Bcl-xL did not inhibit the early activation of caspase-8 ( $<4 \mathrm{~h}$ ) but inhibited cleavage of Bid, suggesting that Bid is cleaved downstream of the mitochondria, independent of caspase-8. Exogenous addition of sphingosine also induced activation of Bax via a caspase-8and Bid-independent mechanism. Further, inhibition of sphingosine kinase completely protected cells from TRAILinduced apoptosis. Data demonstrate that in RMS cells, the TRAIL signaling pathway circumvents caspase- 8 activation of Bid upstream of the mitochondria and that TRAIL acts at the level of the mitochondria via a mechanism that may involve components of the sphingomyelin cycle.

Cell Death and Differentiation (2003) 10, 729-739. doi:10.1038/ sj.cdd. 4401232
Keywords: TRAIL; RMS; apoptosis; Bax activation; FADDdependent; caspase-8-independent; sphingosine

\begin{abstract}
Abbreviations: TRAIL, tumor necrosis factor-related apoptosis inducing ligand (Apo-2L); TNF, tumor necrosis factor; DNFADD, dominant-negative FADD; DNC8, dominant-negative caspase-8; FasL, Fas ligand; IPTG, isopropyl- $\beta$-thio-galactosidase; MAPP, D-erythro (1S, 2R)-D-erythro-2-( $N$-myristoylamino)-1-phenyl-1propanol; DHS, DL-threo-dihydrosphingosine; SPP, sphingosine-1-phosphate; SMase, sphingomyelinase.
\end{abstract}

\section{Introduction}

Tumor necrosis factor (TNF)-related apoptosis inducing ligand (TRAIL/Apo-2L) is a member of the TNF family of death-inducing ligands that include FasL (Apo-1L; CD95) and TNF- $\alpha$ (reviewed in Ashkenazi and Dixit ${ }^{1}$ ). TRAIL binds to at least four membrane-bound receptors, of which two (DR4, DR5) contain a functional death domain capable of transmitting an apoptotic signal. ${ }^{2-4}$ DcR1 lacking an intracellular domain, ${ }^{5,6}$ and DcR2 containing a truncated death domain, ${ }^{7,8}$ are decoy receptors that bind TRAIL without transmission of a cell death signal. Few normal cell populations are sensitive to TRAIL, ${ }^{1,9}$ in contrast to diverse types of malignant and transformed cell lines, which are highly sensitive to TRAIL. ${ }^{1}$ TRAIL resistance in malignant cells has not generally correlated with the relative levels of expression of DR4 and DR5 or the decoy receptors, ${ }^{10}$ suggesting the involvement of alternate mechanisms.

In TRAIL signaling and apoptosis, following ligation of TRAIL to DR4 or DR5 and trimerization of the receptor, a death-inducing signaling complex (DISC) is formed by recruitment of both FADD and procaspase- $8 .{ }^{11-13}$ The role of FADD as the main adaptor protein has been debated since overexpression of DR4 induced cell death in FADD-deficient mouse embryonic fibroblasts, ${ }^{14}$ and a dominant-negative FADD (DNFADD) did not inhibit TRAIL-induced apoptosis in activated $T$ lymphocytes. ${ }^{15}$ Caspase- 8 is activated in the DISC, which can be inhibited by simultaneous recruitment of the inhibitory protein C-FLIP, ${ }^{16,17}$ analogous to the recruitment of these proteins to the Fas complex. The role of caspase- 8 in death receptor-induced apoptosis has been established in experiments in mouse embryonic fibroblasts from caspase-8 'knockout' mouse embryos. ${ }^{18}$ However, the majority of data in this regard have been generated by using the synthetic caspase-8 inhibitor IETD-FMK, although the specificity of these chemical inhibitors is limited. ${ }^{19}$ Since caspase-8 'knockout' is lethal in embryos, studies examining death receptor sensitivity in various differentiated tissues have not been possible. We therefore sought to study the role of FADD and caspase-8 in TRAIL-induced apoptosis in a specific 
histiotype of malignant rhabdomyoblasts by specifically employing dominant-negative constructs of these proteins. We also employed Bcl-xL and Bcl-2 to identify the involvement of the mitochondrial pathway in TRAIL-induced cytotoxicity in these cells.

Depending on the cell type, downstream of DISC formation caspase- 8 can directly activate caspase- 3 and downstream effector caspases and initiate apoptosis (type $\mathrm{I}^{20}$ ). Alternatively, through an amplification loop mediated via the mitochondria (type II), caspase-8 activates the proapoptotic molecule Bid by cleavage, and truncated Bid translocates to the mitochondria causing the recruitment of Bax. Type II but not type I signaling is inhibited by $\mathrm{Bcl}-2$ and $\mathrm{Bcl}-\mathrm{xL} .{ }^{21}$ Proapoptotic factors are subsequently released into the cytosol including cytochrome $c$, which forms an apoptosome complex with Apaf-1 and caspase-9, promoting activation of caspase-9, caspase-3 and downstream caspases, which also includes caspase-8 in the amplification loop. ${ }^{22}$ A modified type II pathway has also been identified in response to cytotoxic drugs and UV radiation, where caspase-3 rather than caspase- 8 catalyzes the cleavage of Bid downstream of the mitochondria, thereby causing a feedback loop for the amplification of mitochondrial cytochrome $c$ release. ${ }^{23}$

Another pathway implicated in death receptor-mediated apoptosis involves the generation of sphingosine and ceramide, which is generated by hydrolysis of the membrane sphingophospholipid sphingomyelin. ${ }^{24}$ Ceramide signaling is involved in cellular responses to a variety of apoptotic stimuli, and ceramide may be produced upon activation of neutral or acidic sphingomyelinases (SMases) or via de novo synthesis by ceramide synthase. ${ }^{25,26}$ The role of this pathway in death receptor-induced apoptosis may depend on cell type and occurs only in type II cells. ${ }^{27-29}$ Natural ceramide has reversed resistance to Fas-mediated apoptosis in acidSMase $-/-$ hepatocytes. ${ }^{30}$ Ceramide and sphingosine act directly at the level of the mitochondria and induce the release of cytotochrome $c$ in a caspase-independent manner, leading to activation of caspase- 9 and executioner caspases together with activation of caspase-8 and the processing of Bid. ${ }^{29}$ However, whether ceramide or sphingosine play a role in TRAIL-induced apoptosis has yet to be elucidated.

In the current study, we demonstrate that in pediatric RMS cells, a DISC is formed in both TRAIL-sensitive and -resistant RMS cell lines with recruitment of FADD and procaspase- 8 to the receptor complexes. Overexpression of $\mathrm{Bcl}-2$ or $\mathrm{Bcl}-\mathrm{xL}$ inhibited TRAIL-induced apoptosis and loss in clonogenic survival, indicating RD cells were type II. Following TRAIL treatment, cleavage of Bid was a late event, the kinetics similar to cleavage of caspase-3 and not caspase-8, and was inhibited by $\mathrm{Bcl}-\mathrm{xL}$. Expression of DNFADD completely inhibited TRAIL-induced apoptosis, in contrast to DNC8, which displayed minimal effect on TRAIL-induced cell death. $\mathrm{Bcl}-2$ and $\mathrm{Bcl}-\mathrm{xL}$, but not DNC8, inhibited TRAIL-induced Bax activation. Exogenous addition of sphingosine also induced activation of Bax via a caspase-8 and Bid independent mechanism, similar to the mechanism of TRAIL-induced Bax activation. Further, inhibition of sphingosine kinase completely protected cells from TRAIL-induced apoptosis. Data demonstrate that in RMS cells, the TRAIL signaling pathway circumvents caspase- 8 activation of Bid upstream of the mitochondria and that TRAIL acts at the level of the mitochondria via a mechanism that may involve the ceramide, sphingosine, and sphingosine-1-phosphate (SPP) signaling pathway.

\section{Results}

\section{TRAIL-induced apoptosis in human RMS cell lines}

Of the six human RMS cell lines examined, apoptosis was induced by TRAIL in RD, Rh30 and Rh18, but not in Rh28, Rh36 or Rh41 (Figure 1; $200 \mathrm{ng} / \mathrm{ml}, 72 \mathrm{~h}$ exposure). RD was the most sensitive line with $72 \%$ apoptosis induced at $72 \mathrm{~h}$, and in Rh30 and Rh18, 60 and 46\% apoptosis, respectively.

\section{DISC formation occurs in TRAIL -sensitive and - resistant RMS cell lines}

Of the two TRAIL receptors that can signal apoptosis, RMS cell lines express DR5 and not DR4 . $^{31}$ Recruitment of FADD and procaspase-8 to DR5 was determined following immunoprecipitation of the DISC from RD, Rh18 and Rh30 following TRAIL exposure (TRAIL-sensitive; $500 \mathrm{ng} / \mathrm{ml}$, 0120 min; Figure 2). In RD cells examined, DISC formation was determined to be maximal at 60 min during TRAIL exposure. DR5 was detected in the DISC as a doublet, consistent with the reported cleavage of the full-length $49 \mathrm{kDa}$ protein into a $43 \mathrm{kDa}$ form. ${ }^{13} \mathrm{RD}, \mathrm{Rh} 18$ and Rh30 express high levels of $\mathrm{C}-$ FLIPL, ${ }^{31}$ and detailed examination of DISC formation in RD demonstrated the presence of c-FLIPL (Figure 2). To examine whether DISC formation was deficient in TRAIL-resistant RMS cell lines, Rh28, Rh36 and Rh41 were treated with TRAIL and the DISCs immunoprecipitated (Figure 2). FADD was recruited to the DISC in all three cell lines. Procaspase-8 was recruited in Rh41, but not in Rh36, where caspase-8 expression was absent. ${ }^{31}$ In Rh28, procaspase-8 was

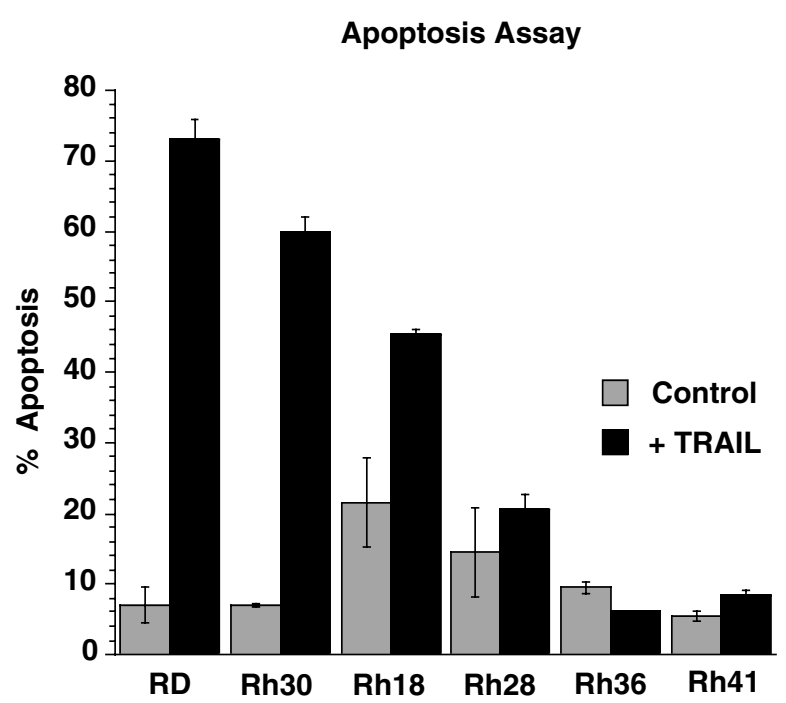

Figure 1 TRAIL-induced apoptosis determined by FACS analysis of the subG1 compartment following exposure to TRAIL $(200 \mathrm{ng} / \mathrm{ml})$ for $72 \mathrm{~h}$. Data represent the mean $\pm S D$ of two determinations at each time point 
a

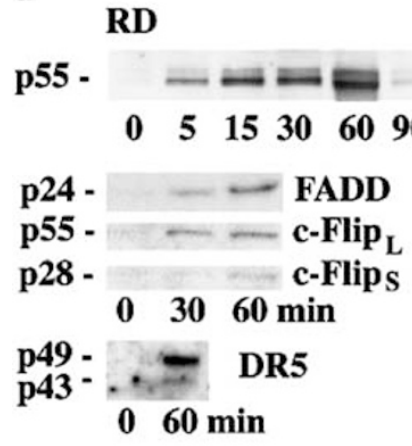

Rh30

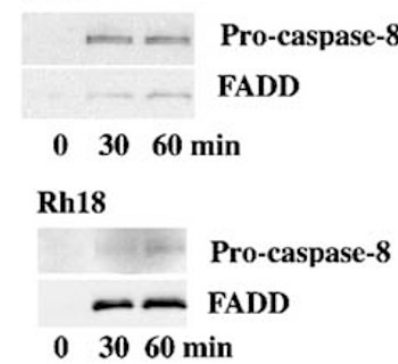

b

\section{Rh41}

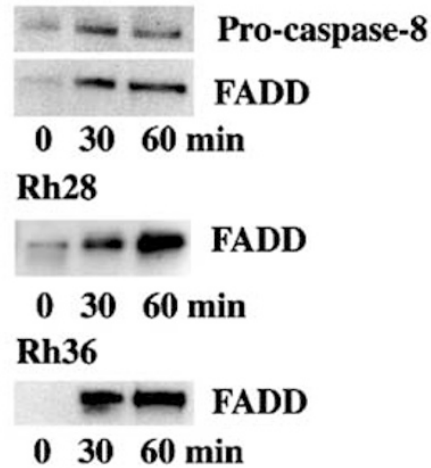

Figure 2 Recruitment of FADD, procaspase-8 and c-FLIP to the DISC immunoprecipitated in (a) TRAIL-sensitive RMS cell lines or (b) TRAIL-resistant RMS cell lines, following treatment of cells with TRAIL (500 ng/ml) for up to $120 \mathrm{~min}$, as described in Materials and Methods. Components of the DISC were probed with specific antibodies as described in Materials and Methods

expressed at a low level, ${ }^{31}$ and hence was visible but difficult to detect within the DISC. C-FLIP expression was absent in Rh28 and Rh36. ${ }^{31}$ TRAIL-resistant cell lines were therefore capable of forming a DISC following ligation of TRAIL to DR5.

\section{TRAIL-induced cell death in RD requires FADD independent of caspase-8}

In TRAIL-sensitive RD cells, retroviral transduction of DNFADD eliminated TRAIL-induced apoptosis as determined by FACS analysis, and completely inhibited TRAIL-induced loss in clonogenic survival (Figure 3 ). In contrast, when RD was transduced with DNC8, only a small reduction $(\approx 10 \%)$ in TRAIL-induced apoptosis was observed (Figure 4a). Similarly, only a marginal reduction in the extent of growth inhibition (Figure 4B) and loss in clonogenic survival (Figure 4c) were observed following TRAIL exposure of DNC8transduced RD cells.

\section{Influence of DNC8 on cleavage of Bid and activation of Bax}

Transduction of RD with DNC8 did not inhibit the cleavage of Bid during the first $16 \mathrm{~h}$ of TRAIL exposure $(200 \mathrm{ng} / \mathrm{ml}$; Figure $5 \mathrm{a}$ ). Further, TRAIL-induced activation of Bax continued in the presence of DNC8 expression (Figure 5b), as determined by Western analysis. However, it was of interest that DNC8 inhibited early caspase-8 activation using a caspase- 8 activity assay, within the first $4 \mathrm{~h}$ of TRAIL exposure, during the time frame when the TRAIL-induced DISC was formed (Figure 5c).

\section{RD cells do not express procaspase-10}

Expression of procaspase-10 was analyzed by Western analysis in the six RMS cell lines and also in Jurkat lymphoma cells. Procaspase-10 was not detected in rhabdomyoblasts, but was expressed at a high level in Jurkat cells (Figure 6).

\section{RD cells are Type II for TRAIL signaling}

In RD cells overexpressing $\mathrm{Bcl}-2$ or $\mathrm{Bcl}-\mathrm{xL}$, TRAIL-induced apoptosis was completely inhibited (Figure 7a) as was TRAILinduced growth inhibition (Figure $7 \mathrm{~b}$ ) and loss in clonogenic survival (Figure 7c), indicating that cells were type II for TRAIL signaling. The influence of expression of DNC8, Bcl-xL or Bcl2 on the activation of Bax in RD cells was subsequently determined (Figure 8). Following transduction with a $\mathrm{Bcl}-2$ or $\mathrm{Bcl}-\mathrm{xL}$ retrovirus, activation of Bax was inhibited within $8 \mathrm{~h}$ of TRAIL exposure. In contrast, in the presence of DNC8, activation of Bax demonstrated no inhibition (Figure 8).

\section{Cleavage of Bid parallels caspase- 3 activation, and is inhibited by Bcl-xL}

The activation of caspases $-8,-9$ and -3 and the cleavage of Bid were examined in RD cells and in RD transduced with a $\mathrm{Bcl}-\mathrm{xL}$ retrovirus, following TRAIL $(200 \mathrm{ng} / \mathrm{ml})$ for up to $24 \mathrm{~h}$ (Figure 9). Procaspase-8 was cleaved to p18-caspase-8 
a

Apoptosis Assay

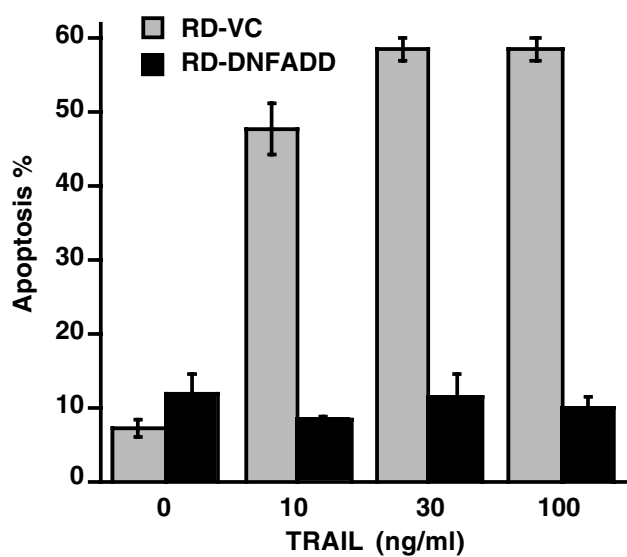

b

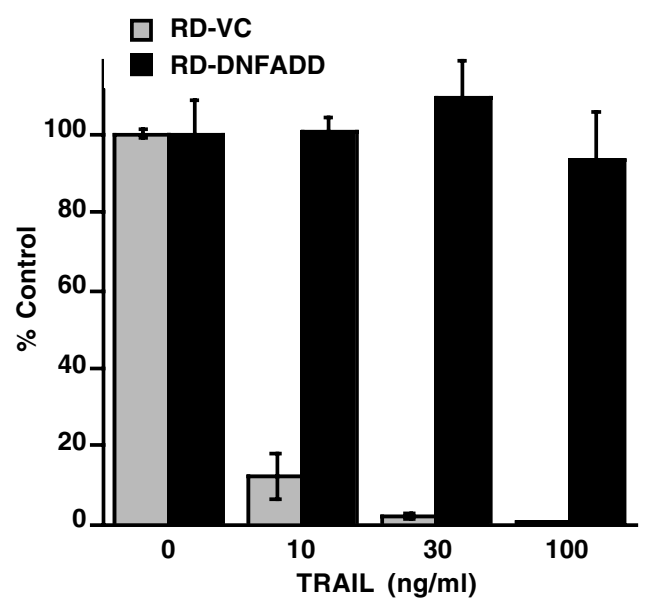

C

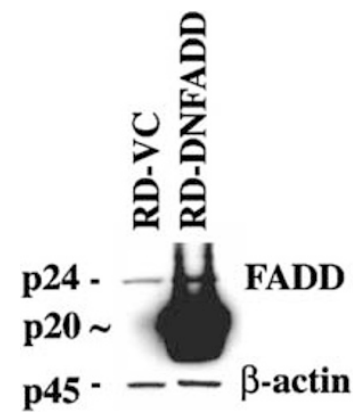

Figure $3 \mathrm{RD}$ cells transduced with retroviral vector alone (RD-VC), or vector containing a DNFADD cDNA, were treated with TRAIL for $24 \mathrm{~h}$ and (a) the extent of apoptosis (subG1) or (b) loss in clonogenic survival were determined. Data represent the mean $\pm S D$ of (a) two or (b) three determinations at each TRAIL concentration. (c) Overexpression of DNFADD in RD cells as described in Materials and Methods

within $1 \mathrm{~h}$ of TRAIL exposure. Activation of caspase-8 increased for the next $3 \mathrm{~h}$ and then subsequently declined. Caspase-8 activation kinetics were not influenced by expression of Bcl-xL. In contrast, the onset of Bid cleavage was detected later $(2-4 \mathrm{~h})$ and continued for $24 \mathrm{~h}$, with kinetics similar to the activation of caspase-3. Caspase- 9 was also cleaved, commencing at $2 \mathrm{~h}$. Cleavage of Bid, caspase- 3 and caspase- 9 were all inhibited by overexpression of $\mathrm{Bcl}-\mathrm{xL}$, suggesting that Bid cleavage occurred downstream of the mitochondria, independent of caspase-8.

\section{Sphingosine induces caspase-8-independent apoptosis and activation of Bax}

Exogenous sphingosine induced apoptosis in a concentration-dependent manner in RD cells after $24 \mathrm{~h}$ incubation (3 $\mu \mathrm{M}, 37 \% ; 10 \mu \mathrm{M}, 71 \% ; 30 \mu \mathrm{M}, 91.5 \%$; Figure $10 \mathrm{a})$. Activated Bax was detected by immunoprecipitation in RD cells commencing at $2 \mathrm{~h}$ following sphingosine $(10 \mu \mathrm{M})$ treatment, either in the presence or absence of a synthetic inhibitor of caspase-8, IETD-FMK $(10 \mu \mathrm{M})$, similar to the kinetics of Bax activation during TRAIL-induced apoptosis. No detectable cleavage of procaspase- 8 or Bid was detected by western analysis (Figure 10b).

\section{Inhibition of sphingosine kinase prevents TRAIL- induced apoptosis}

In this study, the role of ceramidase that converts ceramide to sphingosine using the alkaline ceramidase inhibitor D-erythro (1S, 2R)-D-erythro-2-( $N$-myristoylamino)-1-phenyl-1-propanol (MAPP), and the role of sphingosine kinase using the inhibitor DL-threo-dihydrosphingosine (DHS; Figure 11) were examined (Figure 12). Pretreatment of RD cells with MAPP $(20 \mu \mathrm{M})$ for $4 \mathrm{~h}$ partially inhibited apoptosis induced by low concentrations of TRAIL (3-10 $\mathrm{ng} / \mathrm{ml}$ ) subsequently added for $24 \mathrm{~h}$, but did not significantly affect apoptosis induced at higher TRAIL concentrations (30-100 ng/ml). However, treatment of RD with DHS $(100 \mu \mathrm{M})$ for $4 \mathrm{~h}$ completely inhibited TRAIL-induced apoptosis at all TRAIL concentrations following $24 \mathrm{~h}$ exposure (Figure 12).

\section{Discussion}

\section{A DISC is formed in TRAIL-sensitive and -resistant RMS}

Formation of the DISC is a major initiation step in death receptor-induced apoptosis mediated by members of the TNF receptor superfamily following binding of their specific ligands. 
a

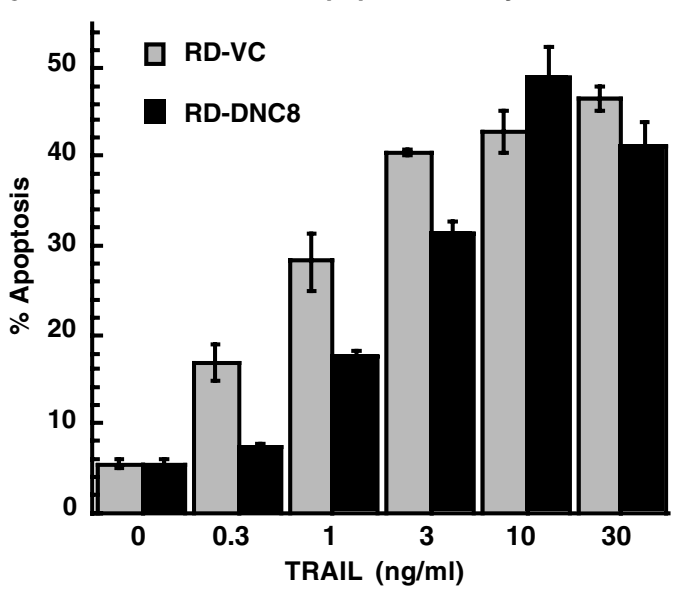

C

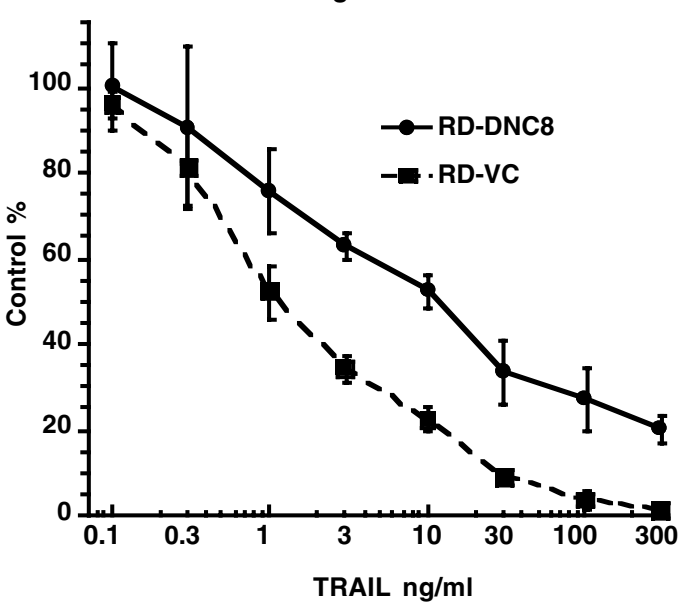

b

Growth Inhibition

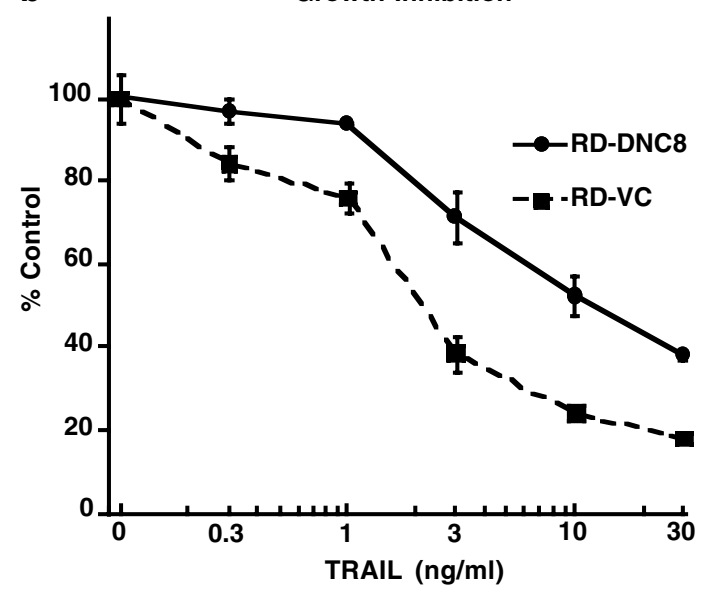

d

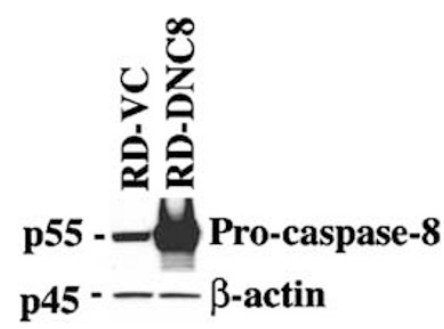

Figure 4 RD cells transduced with retroviral vector alone (RD-VC), or vector containing a DNC8 CDNA, were treated with TRAIL for $24 \mathrm{~h}$ and (a) the extent of apoptosis (sub-G1), (b) influence on growth inhibition or (c) loss in clonogenic survival were subsequently determined. Data represent the mean \pm SD of two determinations at each TRAIL concentration. (d) Overexpression of DNC8 in RD cells was detected by Western analysis as described in Materials and Methods

It has been demonstrated that recruitment of FADD and procaspase- 8 to the DISC following ligation of DR4 and DR5 by TRAIL occurs with subsequent release of active caspase-8 from the DISC in the induction of apoptosis. ${ }^{11-13}$ This is analogous to DISC formation following ligation of Fas. ${ }^{32-37}$ In TRAIL-sensitive RD, Rh18 and Rh30, and TRAIL-resistant Rh28 and Rh41, a DISC was formed among DR5, FADD and procaspase-8, suggesting that the defect(s) in TRAIL signaling in TRAIL-resistant RMS cell lines occurred downstream of DISC formation. However, it is evident that FADD was recruited to the DISC in higher levels in TRAIL-resistant compared to TRAIL-sensitive cell lines, although the reason for this is unknown.

\section{TRAIL-induced cell death requires FADD and mitochondrial signaling, but is independent of caspase-8}

From assays of the sub-G1 fraction by FACS analysis and clonogenic survival following treatment of $\mathrm{RD}$ cells with
TRAIL, cytotoxicity was completely inhibited in the presence of DNFADD, demonstrating the absolute requirement for FADD in TRAIL-induced cell death of RD. Further, cytotoxicity was inhibited by $\mathrm{Bcl}-2$ or $\mathrm{Bcl}-\mathrm{xL}$ overexpresssion, indicating that TRAIL signaling via the mitochondria was required for the induction of cell death, and that RD cells were type II for TRAIL signaling. Caspase- 8 was activated early, by $1 \mathrm{~h}$ after the initiation of TRAIL exposure, and this early event could be inhibited by DNC8. However, of interest was the fact that DNC8 demonstrated little influence on TRAIL-induced cytotoxicity. In typical type II signaling, caspase-8 activation at the DISC is weak, thereby requiring mitochondrial amplification through a feedback loop to generate sufficient activation of downstream effector caspases, including caspase-8, to generate an apoptotic response. ${ }^{20}$ However, caspase-8 activation with the generation of the cleavage product, p18caspase-8, was detected immediately following DISC formation in RD, suggesting that the TRAIL-induced apoptotic signal was independent of caspase-8. Additional support for this concept is demonstrated from the kinetics of activation of caspases 9 and -3 together with the cleavage of Bid, which 
a

RD-VC

$\begin{array}{lllllll}0 & 1 & 2 & 4 & 8 & 16\end{array}$

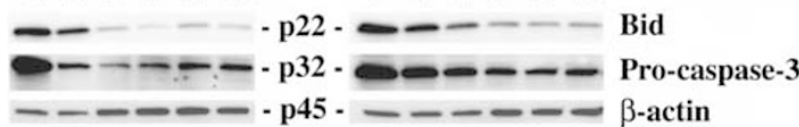

b

RD-VC

$\begin{array}{llllll}0 & 1 & 2 & 4 & 8 & 16\end{array}$

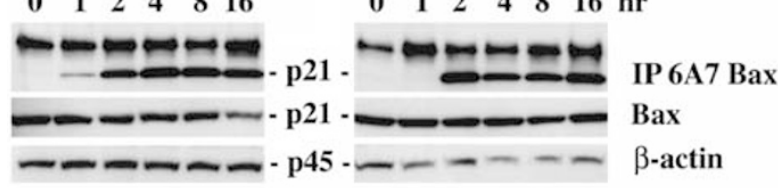

C

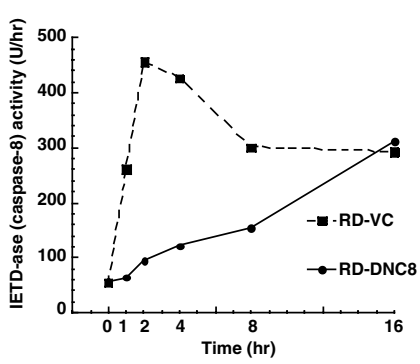

Figure 5 In RD-VC or RD-DNC8 cells, the (a) cleavage of Bid, (b) activation of Bax detected by immunoprecipitation and use of a conformation-specific antibody described in Materials and Methods, and (C) caspase-8 activity were determined following TRAIL $(200 \mathrm{ng} / \mathrm{ml})$ for up to $16 \mathrm{~h}$. The caspase activity assay constitutes a representative experiment from two independent determinations

\section{RD Rh30 Rh18 Rh28 Rh36 Rh41 Jurkat}

Pro-caspase-10

Figure 6 Expression of procaspase-10 in rhabdomyosarcoma cell lines and Jurkat cells determined by western analysis

follows the kinetics of downstream effector caspase activation and not the kinetics of activation of caspase-8. Further, cleavage of all three proteins was inhibited by $\mathrm{Bcl}-\mathrm{xL}$ in contrast to caspase-8 cleavage, which was not inhibited by $\mathrm{Bcl}-\mathrm{xL}$, suggesting that the cleavage of Bid occurred downstream of the mitochondria, via a modified type II signaling pathway previously observed for the induction of apoptosis by chemotherapeutic agents and UV irradiation. ${ }^{23}$ In addition, TRAIL-induced activation of Bax was inhibited by Bcl-xL and Bcl-2 but not by DNC8, suggesting that an alternative mechanism exists for TRAIL-induced activation of Bax at the level of the mitochondria in RD RMS cells, independent of caspase-8.

\section{Lack of role for caspase-10}

In addition to a caspase-8-dependent mechanism, alternative mechanisms of death-receptor-induced cell death have been identified. Recruitment of procaspase-10 to the DISC is considered to be a potential alternative to the recruitment of procaspase-8 in TRAIL-induced apoptosis. In one study, procaspase-10 was detected in the TRAIL-induced DISC of BJAB cells, ${ }^{38}$ although in other cell lines procaspase-10 was not identified as a component of the DISC induced by TRAIL. ${ }^{11,12}$ However, neither RD cells nor other RMS cell lines expressed detectable levels of caspase-10. Therefore, caspase-10 is not responsible for TRAIL-induced caspase-8-independent cell death in RD cells. In peripheral T lymphocytes, RIP was found to induce necrosis independent of caspase-8. ${ }^{39}$ However, downregulation of RIP expression by antisense oligonucleotides has sensitized RD cells to TRAIL-induced apoptosis and inhibited the induction of NF- $\kappa$ B (unpublished observations), suggesting that RIP is a survival factor in this cell type.

\section{Activation of Bax by exogenous sphingosine is independent of Bid and caspase-8}

To explain the lack of effect of early caspase- 8 activation on mitochondrial Bax activation, we sought a mechanism for Bax activation that may be caspase-independent. To this end, the sphingolipids sphingosine and ceramide were considered. Sphingosine is the product of ceramide hydrolysis catalyzed by ceramidases, and has been shown to be rapidly produced during TNF- $\alpha$-mediated apoptosis in human neutrophils ${ }^{40}$ and rat cardiomyocytes. ${ }^{41}$ Sphingosine as well as $\mathrm{C}_{2}$-ceramide have induced cytochrome $c$ release from mitochondria in a caspase-independent manner, leading to the activation of caspase- 9 and effector caspases, and the processing of the substrate Bid, in a Bcl-xL-sensitive manner. ${ }^{42}$ Treatment with exogenous $\mathrm{C}_{2}$-ceramide has also resulted in increased sphingosine levels, and both sphingosine and $\mathrm{C}_{2}$-ceramide have induced apoptosis in Jurkat cells, inhibited by overexpression of $\mathrm{Bcl}-2$, where characteristics of cell death have mirrored Fas-induced apoptosis. ${ }^{42}$ Ceramide-induced apoptosis has also been determined to be Bax dependent. ${ }^{43}$

In Fas-mediated apoptosis, the role of ceramide is controversial. However, resistance to Fas- mediated apoptosis has correlated with resistance to ceramide-mediated apoptosis by virtue of defective release of cytochrome $c$ in human melanoma cells. ${ }^{25}$ Natural ceramide has reversed Fas resistance of acidSMase -/- hepatocytes, derived from acidSMase -/- mice, that are type II cells. ${ }^{30}$

Further, FADD was determined to be required for Fasinduced generation of ceramide in response to Fas ligation, ${ }^{44}$ and for TNF-induced activation of acidSMase. ${ }^{45}$ Data suggest that endogenous ceramide or sphingosine can induce apoptosis in the apoptotic execution phase, independent of events upstream of the mitochondria. However, no evidence is currently available to suggest that sphingolipids may play a role in TRAIL-mediated cell death. We therefore examined the effect of exogenous sphingosine on activation of Bax, and the effect of inhibitors of endogenous sphingosine or SPP synthesis on TRAIL-induced apoptosis in RD rhabdomyoblasts. Clearly, exogenous sphingosine induced apoptosis and activation of Bax, independent of the cleavage of Bid or activation of caspase-8, consistent with the mechanism of TRAIL-induced apoptosis demonstrated in RD. Further, 
a

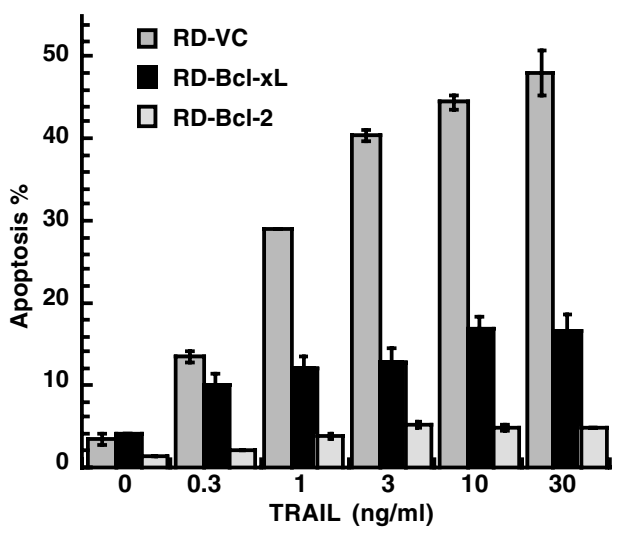

b

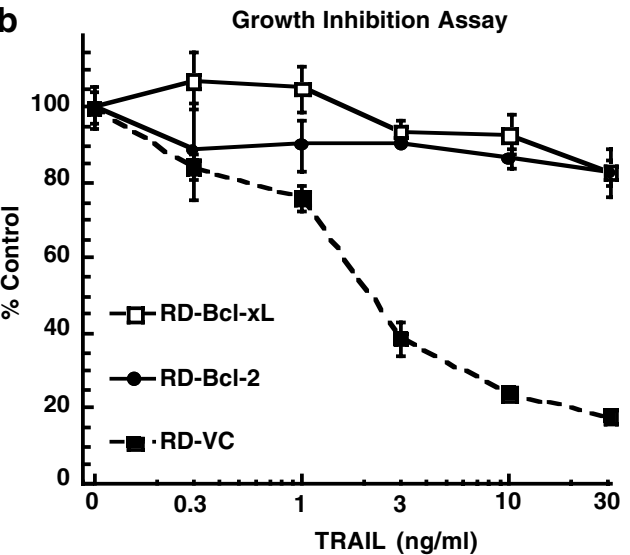

C

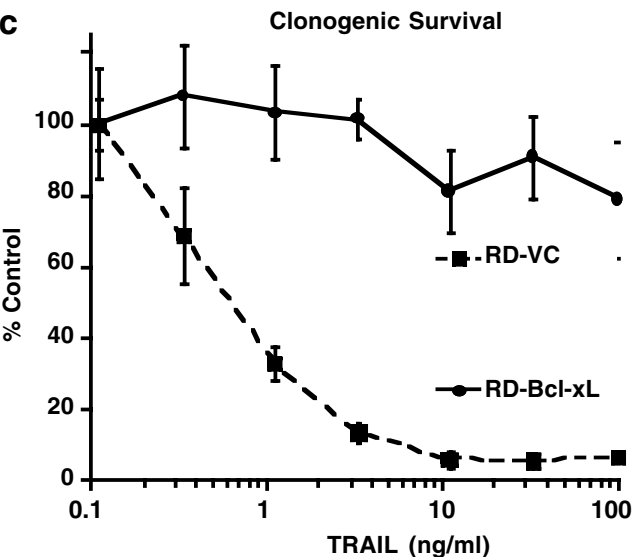

d

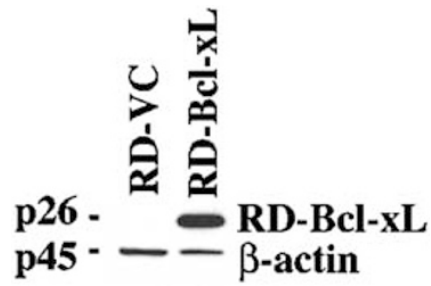

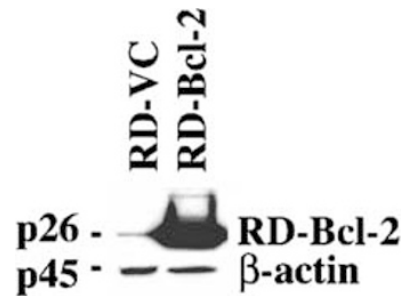

Figure 7 Influence of overexpression of Bcl-2 or Bcl-xL on (a) TRAIL-induced apoptosis (sub-G1), (b) TRAIL-induced growth inhibition and (c) TRAIL-induced loss in clonogenic survival. Data are the mean $\pm \mathrm{SD}$ of $(\mathbf{a})$ two or $(\mathbf{b}, \mathbf{c})$ three determinations per point. (D, E) Level of expression of $\mathrm{Bcl}-\mathrm{xL}$ and $\mathrm{Bcl}-2$, respectively, determined by Western analysis.

pretreatment with DHS, a cell-permeable and competitive inhibitor of sphingosine kinase, completely abrogated the concentration-dependent cell death mediated by TRAIL, thereby implying an essential requirement for SPP in TRAILinduced apoptosis in rhabdomyoblasts. Additionally, inhibition of alkaline ceramidase using MAPP to raise intracellular ceramide levels by blocking the hydrolysis of ceramide to sphingosine thereby limited the amount of sphingosine available for conversion to SPP and inhibited cell death induced at low but not high concentrations of TRAIL. MAPP did not completely inhibit TRAIL-induced apoptosis at low concentrations, and is likely to reflect the involvement of other ceramidases (reviewed in Hannun et al. ${ }^{46}$ ). Our data are suggestive of a primary role for SPP as the primary signaling intermediate in TRAIL-induced apoptosis in RMS cell lines rather than ceramide or sphingosine as would be predicted 
from studies of the signal transduction of the related cytokine family members TNF- $\alpha$ and Fas (reviewed in Hannun and Luberto $^{47}$ ). It is likely that rather than an elevation in a single intermediate of the sphingomyelin cycle being responsible for TRAIL-induced apoptosis, it is the ratios of bioactive lipids capable of intracellular signaling relative to one another that are of importance (see the reviews of Hannun et al. ${ }^{46}$ and Payne et al. ${ }^{48}$ ). Clearly, further investigations are required to elucidate the exact role of the sphingomyelin cycle in TRAILinduced apoptosis of rhabdomyosarcoma cells in vitro.

In summary, we have identified two levels at which TRAIL signaling may be regulated in rhabdomyoblasts: (1) FADD but not caspase- 8 is clearly required for the induction of apoptosis by TRAIL, and (2) the importance of Bax activation independent of caspase-8 is demonstrated. Therefore, between FADD at the level of the DISC and activation of Bax at the level of the mitochondria, there exists a caspase-8-independent pathway for the induction of cell death by TRAIL, which may involve components of the ceramide signaling pathway. It has been demonstrated that once activated, Bax can kill cells independent of caspase activation, and may explain why caspase inhibitors may not inhibit apoptosis in clonogenic survival assays. ${ }^{49}$ It is evident that TRAIL signaling downstream of the mitochondria via a modified type II pathway occurs in RMS cells.

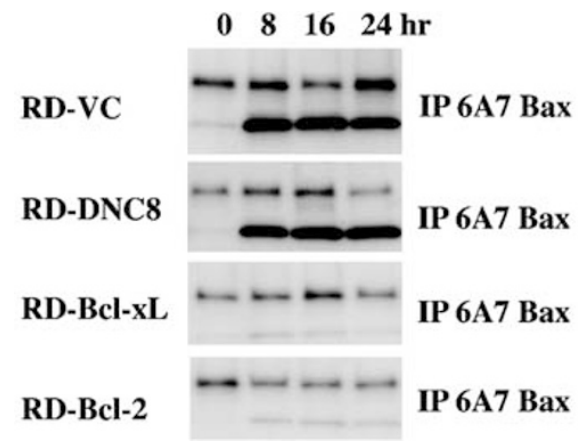

Figure 8 Expression of the activated form of Bax determined by i. p. Mestern analysis in TRAIL- treated (200 ng/ml) RD-VC, RD-DNC8, RD-Bcl-XL or RD-Bcl-2 cells

\section{Materials and Methods}

\section{Cell lines}

Rh18, Rh28, Rh30, Rh36 and Rh41 cell lines utilized in this study were established at SJCRH. RD and Jurkat cell lines were obtained from ATCC. Characteristics of four cell lines have been described. ${ }^{50-52}$ RMS cell lines were cultured in RPMI 1640 medium containing 10\%FBS (Gibco), as described.

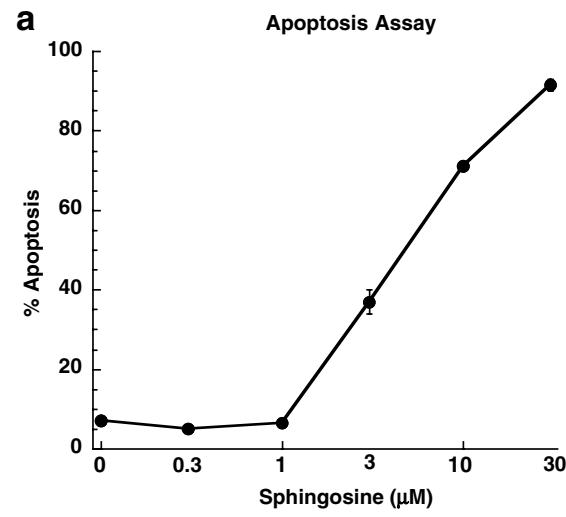

b

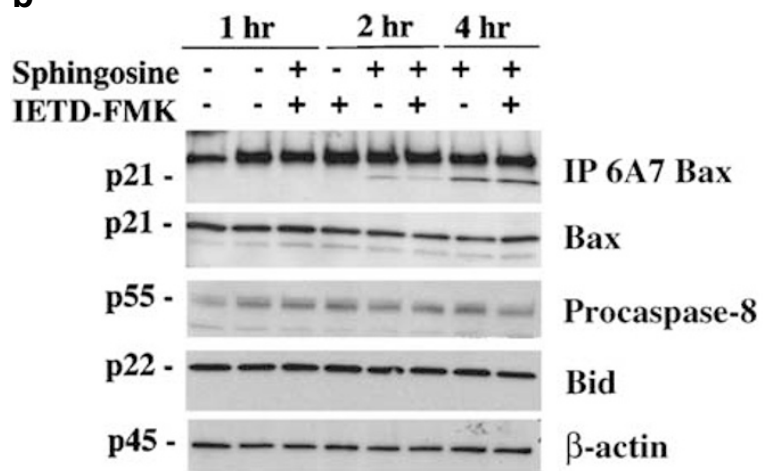

Figure 10 (a) Increasing concentrations of sphingosine $(0.3-30 \mu \mathrm{M})$ induced apoptosis (sub-G1) in RD cells following exposure for $24 \mathrm{~h}$. Data represent the mean $\pm S D$ of two determinations at each time point. (b) Activation of Bax and levels of procaspase-8, Bid and $\beta$-actin determined by i. p./Western analysis in RD cells treated with sphingosine $(10 \mu \mathrm{M})$ for increasing incubation times

\section{RD-VC}

RD-Bcl-xL

\section{$\begin{array}{llllllll} & 1 & 2 & 4 & 8 & 16 & 24 & h r\end{array}$}

\section{$\begin{array}{lllllllll}0 & 1 & 2 & 4 & 8 & 16 & 24 & \text { hr }\end{array}$}

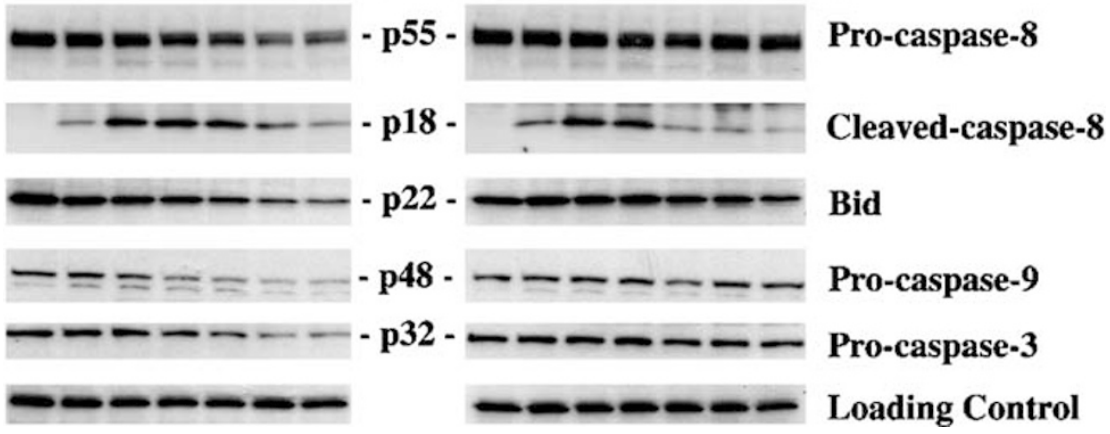

Figure 9 Cleavage of caspase-8 and expression of Bid, procaspase-9 and procaspase-3 during treatment of RD-VC or RD-Bcl-xL for up to $24 \mathrm{~h}$ with TRAIL (200 $\mathrm{ng} /$ $\mathrm{ml})$. Expression was determined by Western analysis 


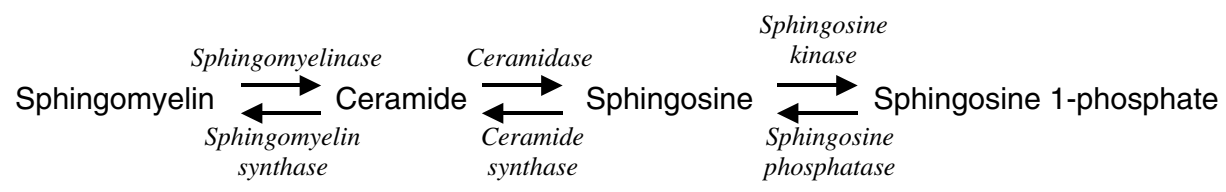

Figure 11 Partial sphingomyelin cycle relevant to metabolic inhibitors used in the study

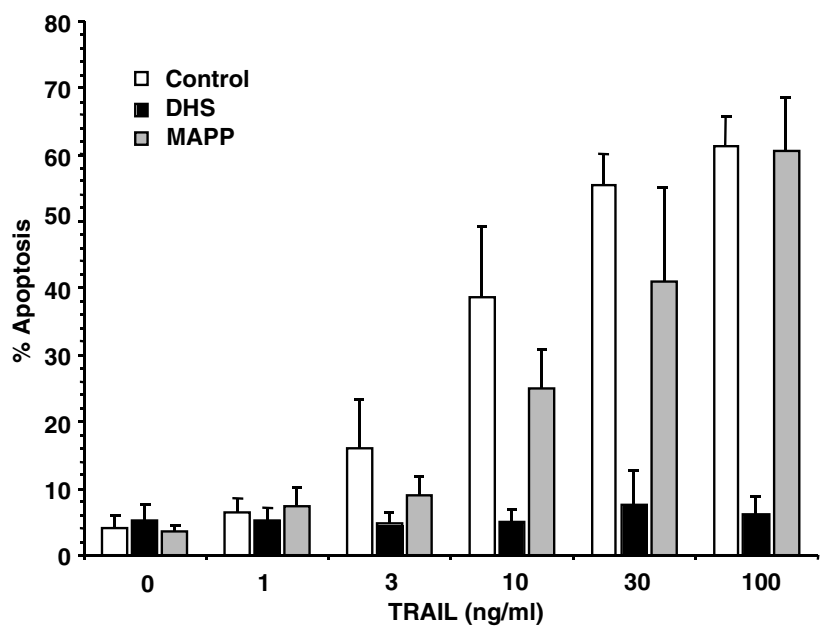

Figure 12 Inhibitors of ceramidase and sphingosine kinase prevent TRAILinduced apoptosis in RD cells. Cells were pretreated with MAPP $(20 \mu \mathrm{M})$ or DHS $(100 \mu \mathrm{M})$ for $4 \mathrm{~h}$ prior to exposure to TRAIL for a further $24 \mathrm{~h}$. Apoptosis was determined by FACS analysis of the sub-G1 compartment. Data represent the mean \pm SD of 10 determinations.

\section{Production of recombinant human TRAIL}

The CDNA of the extracellular domain of TRAIL corresponding to amino acids 114-281 was subcloned into the $p E T 17 / b$ (Novagen) bacterial expression vector and expressed in the BL21(DE3) pLysE (Novagen) bacterial host. Following induction of TRAIL expression using isopropyl- $\beta$ thio-galactosidase (IPTG; $1 \mathrm{mM}$ ), bacterial pellets were harvested, and TRAIL was purified following passage through a nickel column (Ni-NTA) followed by a size exclusion column (Amersham), according to published procedures. $^{53}$

\section{Measurement of apoptosis}

Malignant myoblasts were plated at a density of 400000-500 000 cells/ well in six-well plates. Following overnight attachment, cells were treated for $72 \mathrm{~h}$ with TRAIL $(200 \mathrm{ng} / \mathrm{ml})$ or for $24 \mathrm{~h}$ in the concentration range of $0.3-100 \mathrm{ng} / \mathrm{ml}$. In additional experiments, RD cells were treated under the same conditions with increasing concentrations of sphingosine $(0.3-$ $30 \mu \mathrm{M}$; Calbiochem;\#567725) for $24 \mathrm{~h}$, or pretreated with MAPP (20 $\mu \mathrm{M}$;Biomol;\#SL221) or DHS (100 $\mu \mathrm{M}$;Biomol;\#SL205) prior to TRAIL $(1-100 \mathrm{ng} / \mathrm{ml})$ for a further $24 \mathrm{~h}$. Both the floating cells and attached cells were pooled following trypsinization, fixed in $70 \%$ ethanol, and stored at $-20^{\circ} \mathrm{C}$ prior to analysis. Apoptotic cells were detected as a sub-G1 fraction following propidium iodide staining and analysis using a Becton Dickinson FACScan. ${ }^{54,55}$

\section{Clonogenic survival}

$\mathrm{RD}$ was plated at a density of 3000 cells per well in $2 \mathrm{ml}$ medium. Following overnight attachment, cells were treated for $72 \mathrm{~h}$ with TRAlL $(1-100 \mathrm{ng} /$ $\mathrm{ml}$ ). Clonogenic survival was determined after a further 7 days, as described previously. ${ }^{31}$

\section{DISC formation}

Immunoprecipitation of receptor complexes following treatment of RD or Rh30 cells for time periods up to $120 \mathrm{~min}$ with $500 \mathrm{ng} / \mathrm{ml}$ flag-tagged TRAIL (Upstate), and analysis of components of the DISC were conducted as described by Bodmer et al. ${ }^{11}$ Proteins were evaluated by western analysis described below.

\section{Western analyses}

Western analyses were conducted as described. ${ }^{20,31}$ Primary antibodies employed were:caspase-8 (MBL;\#M058-3), caspase-9 (MBL;\#M054-3), caspase-10 (MBL;\#M059-3), FADD (Transduction Laboratories; \#F36620), c-FLIP (Kamiya;\#PC-020), caspase-3 (BD; \#556425), Bid (BD;\#550365), Bax (BD; \#554104) and actin (Sigma; A4700). Secondary antibodies were HRPO-conjugated goat anti-mouse IgG1 and rabbit antigoat IgG (Southern Biotechnology), and sheep-anti-mouse Ig and donkey anti-rabbit Ig (Amersham). Activation of caspase-8, -3 and -9 was determined by the decrease of procaspase protein levels and by the detection of cleaved fragments of active caspases. Cleavage of Bid was examined by the loss of the full-length $(22 \mathrm{kDa})$ protein.

\section{Retroviral expression vectors}

The retroviral expression vectors pMSCV-I-GFP (expressing GFP) and pMSCV-DNC8, (expressing dominant-negative mutant caspase-8, and GFP separated by an IRES sequence) and pMSCV-DNFADD (expressing the death domain only of FADD) were kind gifts from Dr. Jill M Lahti and Dr Vincent J. Kidd (St. Jude Children's Research Hospital, Memphis, TN, USA) and have been described previously. ${ }^{56}$ pMSCV-Bcl-2, which expresses human Bcl-2 protein, was kindly provided by Dr. John Cleveland (St. Jude Children's Research Hospital, Memphis, TN, USA). pMSCV-Bcl- $\mathrm{xL}$, which expresses the human $\mathrm{Bcl}-\mathrm{xL}$, was generated by subcloning the human $B c l-x L C D N A$ into the EcoR1 site of the pMSCV-IGFP vector. Retroviral supernatants were prepared as previously described. ${ }^{57} \mathrm{RD}$ cells were incubated overnight in a $50 \%$ mixture of RPMI 1640 medium and supernatant in the presence of polybrene $(8 \mu \mathrm{g} /$ $\mathrm{ml}$;Sigma). After replacement of this medium with fresh viral supernatants and culture media, $\mathrm{RD}$ cells were incubated at $37^{\circ} \mathrm{C}$ for an additional $48 \mathrm{~h}$. The viral-transferred cells were sorted by expression of GFP using fluorescence-activated cell sorting, and stable GFP-positive cells were selected. The expression of DNFADD (indicated by the presence of a lower molecular weight band of the truncated protein), DNC8, Bcl-2 and $\mathrm{Bcl}-\mathrm{xL}$ was confirmed by Western blotting. $\mathrm{RD}\left(2 \times 10^{6}\right)$ cells transfected with retroviral expression vectors (VC, DNC8, Bcl- $\mathrm{xL}$ ) were plated in $10 \mathrm{~cm}$ culture dishes (Corning), and after overnight attachment the cells were treated with TRAIL $(200 \mathrm{ng} / \mathrm{ml})$ for increasing incubation times. Subsequently, both floating and attached cells were collected and analyzed by Western blotting. 


\section{Immunoprecipitation of active Bax}

To detect conformationally active Bax, RD cells were transduced with retroviral expression vectors and treated in 50\% confluent T175 flasks (Falcon) with TRAIL $(200 \mathrm{ng} / \mathrm{ml})$ or with sphingosine $(10 \mu \mathrm{M})$ in the presence or absence of the synthetic caspase-8 inhibitor IETD-FMK (10 $\mu \mathrm{M}$;Enzyme Systems Products) for increasing incubation times. Both attached and floating cells were collected and lysed in CHAPS lysis buffer. ${ }^{58}$ After preclearing, the activated Bax immunoprecipitated with the monoclonal antibody clone $6 \mathrm{~A} 7$ (BD;\#5564871), which reacts only with Bax in its conformationally active state in this buffer. Bax was detected by polyclonal anti-Bax serum (BD; \#554104).

\section{Caspase activity assay}

Caspase activity was determined according to the manufacturer's instructions (Clontech; ApoAlert caspase-8 (\#K2028)). Transduced RD cells $\left(2 \times 10^{6}\right.$; (RD-VC, RD-DNC8) were plated in $10 \mathrm{~cm}$ culture dishes (Corning). After overnight attachment, cells were treated with TRAIL $(1 \mu \mathrm{g} / \mathrm{ml})$ for increasing incubation times. Both floating and attached cells were collected. Caspase activity in cell lysates was determined from the fluorescence of the cleaved (AFC) substrate measured in a fluorometer.

\section{Acknowledgements}

This research was supported by NIH Awards CA 87952, CA 23099, CA 23944, and by the American Lebanese Syrian Associated Charities.

\section{References}

1. Ashkenazi $A$ and Dixit V (1998) Death receptors:signaling and modulation. Science 281: 1305-1308

2. Pan G, O'Rourke K, Chinnaiyan AM, Gentz R, Ebner R, Ni J and Dixit VM (1997) The receptor for the cytotoxic ligand TRAIL. Science 276: 111-113

3. Walczak H, Degli-Esposti M, Johnson RS, Smolak PJ, Waugh JY, Boiani N, Timour MS, Gerhart MJ, Schooley KA, Smith CA, Goodwin RG and Rauch CT (1997) TRAIL-R2: a novel apoptosis-mediating receptor for TRAIL. EMBO J. 16: $5386-5397$

4. Wu GS, Burns TF, McRonald ER, Jiang W, Meng R, Krantz ID, Kao G, Gan DD, Zhou J-Y, Muschel R, Hamilton SR, Spinner NB, Markowitz S, Wu G and ElDeiry W (1997) KILLER/DR5 is a DNA damage-inducible p53-regulated death receptor gene. Nat. Genet. 17: 141-143

5. Sheridan JP, Marsters, SA, Pitti RM, Gurney A, Skubatch M, Baldwin D, Ramakrishnan L, Gray, CL, Baker K, Wood WI, Goddard AD, Godowski P and Ashkenazi A (1997) Control of TRAIL- induced apoptosis by a family of signaling and decoy receptors. Science 277: 818-821

6. Pan G, Ni J, Wei YF, Yu G, Gentz R and Dixit VM (1997) An antagonist decoy receptor and a death domain-containing receptor for TRAIL. Science 277: 815-818

7. Degli-Esposti MA, Dougall WC, Smolak PJ, Waugh JY, Smith CA and Goodwin RG (1997) The novel receptor TRAIL-R4 induces NF-kappaB and protects against TRAIL-mediated apoptosis, yet retains an incomplete death domain. Immunity 7: 813-820

8. Marsters SA, Sheridan JP, Pitti RM, Huang A, Skubatch M, Baldwin D, Yuan J, Gurney A, Goddard AD, Godowski P and Ashkenazi A (1997) A novel receptor for Apo2L/TRAIL contains a truncated death domain. Curr. Biol. 7: 1003-1006

9. Jeremias I, Herr I, Boehler T and Debatin KM (1998) TRAIL/Apo-2-ligandinduced apoptosis in human T cells. Eur. J. Immunol. 28: 143-152

10. Griffith TS and Lynch DH (1998) TRAIL: a molecule with multiple receptors and control mechanisms. Curr. Opin. Immunol. 10: 559-563

11. Bodmer JL, Holler N, Reynard S, Vinciguerra P, Schneider P, Juo P, Blenis J and Tschopp J (2000) TRAIL receptor-2 signals apoptosis through FADD and caspase-8. Nat. Cell Biol. 2: 241-243
12. Sprick MR, Weigand MA, Rieser E, Rauch CT, Juo P, Blenis J, Krammer PH and Walczak H (2000) FADD/MORT1 and caspase-8 are recruited to TRAIL receptors 1 and 2 and are essential for apoptosis mediated by TRAIL receptor 2. Immunity 12: 599-609

13. Kischkel FC, Lawrence DA, Chuntharapai A, Schow P, Kim KJ and Ashkenazi A (2000) Apo2L/TRAIL-dependent recruitment of endogenous FADD and caspase-8 to death receptors 4 and 5 . Immunity 12: 611-620

14. Yeh W-C, de la Pompa JL, McCurrach ME, Shu H-B, Elia AJ, Shahinian A, Ng M, Wakeham A, Khoo W, Mitchell K, El-Deiry WS, Lowe SW, Goeddel DV and Mak TW (1998) FADD: essential for embryo development and signaling from some, but not all, inducers of apoptosis. Science 279: 1954-1958

15. Marsters SA, Pitti RM, Donahue CJ, Ruppert S, Bauer KD and Ashkenazi A (1996) Activation of apoptosis by Apo-2 ligand is independent of FADD but blocked by CrmA. Curr. Biol. 6: 750-752

16. Griffith TS, Chin WA, Jackson GC, Lynch DH and Kubin MZ (1998) Intracellular regulation of TRAIL-induced apoptosis in human melanoma cells. J. Immunol. 161: $2833-2840$

17. Schneider $P$, Thome T, Burns K, Bodmer JL, Hofmann K, Kataoka T, Holler $N$ and Tschopp J (1997) TRAIL receptors 1 (DR4) and 2 (DR5) signal FADDdependent apoptosis and activate NF- kappaB. Immunity 7: 831-836

18. Varfolomeev EE, Schuchmann M, Luria V, Chiannilkulchai N, Beckmann JS, Mett IL, Rebrikov D, Brodianski VM, Kemper OC, Kollet O, Lapidot T, Soffer D, Avraham KB, Goncharov T, Holtmann H, Lonai P and Wallach D (1998) Targeted disruption of the mouse caspase 8 gene ablates cell death induction by the TNF receptors, Fas/Apo1, and DR3 and is lethal prenatally. Immunity 9 : 267-276

19. Garcia-Calvo M, Peterson EP, Leiting B, Ruel R, Nicholson DW and Thornberry NA (1998) Inhibition of human caspases by peptide-based and macromolecular inhibitors. J. Biol. Chem. 273: 32608-32613

20. Scaffidi C, Fulda S, Srinivasan A, Friesen C, Li F, Tomaselli KJ, Debatin KM, Krammer PH and Peter ME (1998) Two CD95 (APO-1/Fas) signaling pathways. EMBO J. 17: 1675-1687

21. Fulda S, Meyer E, Friesen C, Susin SA, Kroemer G and Debatin KM (2001) Cell type specific involvement of death receptor and mitochondrial pathways in drug-induced apoptosis. Oncogene 20: 1063-1075

22. Kroemer G and Reed JC (2000) Mitochondrial control of cell death. Nat. Med. 6: 513-519

23. Slee EA, Keogh, SA and Martin SJ (2000) Cleavage of BID during cytotoxic drug and UV radiation-induced apoptosis occurs downstream of the point of $\mathrm{Bcl}-2$ action and is catalysed by caspase-3: a potential feedback loop for amplification of apoptosis-associated mitochondrial cytochrome $c$ release. Cell Death Differ 7: 556-565

24. Hannun YA (1994) The sphingomyelin cycle and the second messenger function of ceramide. J. Biol. Chem. 269: 3125-3128

25. Geilen CC, Wieder T and Orfanos CE (1997) Ceramide signalling: regulatory role in cell proliferation, differentiation and apoptosis in human epidermis. Arch. Dermatol. Res. 289: 559-566.

26. Raisova M, Bektas M, Wieder T, Daniel P, Eberle J, Orfanos CE and Geilen CC (2000) Resistance to CD95/Fas-induced and ceramide-mediated apoptosis of human melanoma cells is caused by a defective mitochondrial cytochrome $c$ release. FEBS Lett. 473: 27-32

27. Scaffidi C, Schmitz I, Zha J, Korsmeyer SJ, Krammer PH and Peter M (1999) Differential modulation of apoptosis sensitivity in CD95 type I and type II cells. J. Biol. Chem. 274: 29502-29508

28. Lin T, Genestier L, Pinkoski MJ, Castro A, Nicholas S, Mogil R, Paris F, Fuks Z, Schuchman EH, Kolesnick RN and Green DR (2000) Role of acidic sphingomyelinase in Fas/CD95-mediated cell death. J. Biol. Chem. 275: 8657-8663

29. Cuvillier $O$, Edsall $L$ and Spiegel $S$ (2000) Involvement of sphingosine in mitochondria-dependent Fas-induced apoptosis of type II Jurkat T cells. J. Biol. Chem. 275: 15691-15700

30. Paris F, Grassme H, Cremesti A, Zager J, Fong Y, Haimovitz-Friedman A, Fuks Z, Gulbins E and Kolesnick R (2001) Natural ceramide reverses Fas resistance of acid sphingomyelinase $-1-$ hepatocytes. J. Biol. Chem. 276: 8297-8305

31. Petak I, Douglas L, Tillman DM, Vernes R and Houghton JA (2000) Pediatric rhabdomyosarcoma cell lines are resistant to Fas-induced apoptosis and highly sensitive to TRAIL-induced apoptosis. Clin. Cancer Res. 6: 4119-4127 
32. Boldin MP, Goncharov TM, Goltseve YV and Wallach D (1996) Involvement of $\mathrm{MACH}$, a novel MORT1/FADD-interacting protease, in Fas/APO-1-and TNF receptor-induced cell death. Cell 85: 803-815

33. Muzio M, Chinnaiyan AM, Kischkel FC, O'Rourke K, Shevchenko A, Ni J, Scaffidi C, Bretz JD, Zhang M, Gentz R, Mann M, Krammer PH, Peter ME and Dixit VM (1996) FLICE, a novel FADD- homologous ICE/CED-3-like protease, is recruited to the CD95 (Fas/APO-1) death-inducing signaling complex. Cell 85: $817-827$

34. Tschopp J, Irmler M and Thome M (1998) Inhibition of Fas death signals by FLIPs. Curr. Opin. Immunol. 10: 552-558

35. Krueger A, Schmitz I, Baumann S, Krammer PH and Kirchhoff S (2001) Cellular FLICE- inhibitory protein splice variants inhibit different steps of caspase-8 activation at the CD95 death- inducing signaling complex. J. Biol. Chem. 276: 20633-20640

36. Scaffidi C, Schmitz I, Krammer PH and Peter ME (1999) The role of c-FLIP in modulation of CD95-induced apoptosis. J. Biol. Chem. 15 $1541-1548$

37. Kataoka T, Budd RC, Holler N, Thome M, Martinon F, Irmler M, Burns K, Hahne M, Kennedy N, Kovacsovics, M and Tschopp, J (2000) The caspase-8 inhibitor FLIP promotes activation of NF-kappaB and Erk signaling pathways. Curr. Biol. 10: $640-648$

38. Kischkel FC, Lawrence DA, Tinel A, LeBlanc H, Virmani A, Schow P, Gazdar A, Blenis J, Arnott D and Ashkenazi A (2001) Death receptor recruitment of endogenous caspase-10 and apoptosis initiation in the absence of caspase-8. J. Biol. Chem. 276: 40639-40646

39. Holler N, Zaru R, Micheau O, Thome M, Attinger A, Valitutti S, Bodmer JL, Schneider P, Seed B and Tschopp J (2000) Fas triggers an alternative, caspase-8-independent cell death pathway using the kinase RIP as effector molecule. Nat. Immunol. 1: 489-495

40. Ohta H, Yatomi Y, Sweeney EA, Hakomori S and Igarashi Y (1994) A possible role of sphingosine in induction of apoptosis by tumor necrosis factor-alpha in human neutrophils. FEBS Lett. 355: 267-270

41. Krown KA, Page MT, Nguyen C, Zechner D, Gutierrez V, Cornstock KL, Glembotski CC, Quintana PJ and Sabbadini RA (1996) Tumor necrosis factor alpha-induced apoptosis in cardiac myocytes. Involvement of the sphingolipid signaling cascade in cardiac cell death. J. Clin. Invest. 98: 2854-2865

42. Cuvillier O, Edsall L and Spiegel S (2000) Involvement of sphingosine in mitochondria-dependent Fas-induced apoptosis of type II Jurkat T cells. J. Biol. Chem. 275: 15691-15700

43. Kim HJ, Mun JY, Chun YJ, Choi KH and Kim MY (2001) Bax-dependent apoptosis induced by ceramide in HL-60 cells. FEBS Lett. 505: 264-268

44. Juo P, Woo MS-A, Kuo CJ, Signorelli P, Biemann HP, Hannun YA and Blenis J (1999) FADD is required for multiple signaling events downstream of the receptor Fas. Cell Growth Differ. 10: 797-804
45. Wiegmann K, Schwandner R, Krut O, Yeh W-C, Mak TW and Kronke M (1999) Requirement of FADD for tumor necrosis factor-induced activation of acid sphingomyelinase. J. Biol. Chem. 274: 5267-5270

46. Hannun YA, Luberto $C$ and Argraves KM (2001) Enzymes of sphingolipid metabolism: from modular to integrative signaling. Biochemistry 40: 4893-4903

47. Hannun YA and Luberto $C(2000)$ Ceramide in the eukaryotic stress response. Trends Cell Biol. 1073-1080

48. Payne SG, Milstien S and Spiegel S (2000) Sphingosine-1-phosphate: dual messenger functions. FEBS Lett. 531: 54-57

49. Gross A, Jockel J, Wei MC and Korsmeyer SJ (1998) Enforced dimerization of Bax results in its translocation, mitochondrial dysfunction, and apoptosis. EMBO J. 17: 3878-3885

50. Hazelton BJ, Houghton JA, Parham DM, Douglass EC, Torrance PM, Holt $\mathrm{H}$ and Houghton PJ (1987) Characterization of cell lines derived from xenografts of childhood rhabdomyosarcoma. Cancer Res. 47: 4501-4507

51. McPake CR, Tillman DM, Poquette CA, George EO, Houghton JA and Harris LC (1998) Bax is an important determinant of chemosensitivity in pediatric tumor cell lines independent of Bcl-2 expression and p53 status. Oncol Res. 10: $235-244$

52. Hosoi H, Dilling MB, Shikata T, Liu N, Ashmun RA, Germain GS, Abraham RT and Houghton PJ (1999) Rapamycin causes poorly reversible inhibition of mTOR and induces p53-independent apoptosis in human rhabdomyosarcoma cells. Cancer Res. 59: 886-894

53. Ashkenazi A, Pai RC, Fong S, Leung S, Lawrence DA, Marsters SA, Blackie C, Chang L, McMurtrey AE, Hebert A, DeForge L, Koumenis IL, Lewis D, Harris L, Bussiere J, Koeppen H, Shahrokh Z and Schwall RH (1999) Safety and antitumor activity of recombinant soluble Apo2 ligand. J Clin Invest. 104: 155162

54. Gong J, Traganos F and Darznkiewicz Z (1994) A selective procedure for DNA extraction from apoptotic cells applicable for gel electrophoresis and flow cytometry. Anal Biochem. 218: 314-319

55. Mihalik R, Uher F, Berczy L, Pocsik E, Benczur M and Kopper L (1996) Detection of drug-induced apoptosis by flow cytometry after alkaline extraction of ethanol fixed cells. Pathol. Oncol. Res. 2: 78-83

56. Teitz T, Wei T, Valentine MB, Vanin EF, Grenet J, Valentine VA, Behm FG, Look AT, Lahti JM and Kidd VJ (2000) Caspase 8 is deleted or silenced preferentially in childhood neuroblastomas with amplification of MYCN. Nat. Med. 6: 529-535

57. Persons DA, Allay JA, Allay ER, Ashmun RA, Orlic D, Jane SM, Cunningham JM and Nienhuis AW (1999) Enforced expression of the GATA-2 transcription factor blocks normal hematopoiesis. Blood 93: 488-499

58. Murphy KM, Streips UN and Lock RB (2000) Bcl-2 inhibits a Fas-induced conformational change in the $\mathrm{Bax} \mathrm{N}$ terminus and $\mathrm{Bax}$ mitochondrial translocation. J. Biol. Chem. 275: 17225-17228 